\title{
The Quality and Health Implications of Urban Irrigation Water Used for Vegetable Production in the Accra Metropolis
}

\author{
Mark O. Akrong ${ }^{1}$, Joseph A. Ampofo ${ }^{1}$, Seth K. A. Danso ${ }^{2}$ \\ ${ }^{1}$ CSIR-Water Research Institute, Accra, Ghana; ${ }^{2}$ Department of Soil Science, University of Ghana, Legon, Ghana. \\ Email: markosaakrong@yahoo.com
}

Received July $18^{\text {th }}, 2012$; revised August $17^{\text {th }}, 2012$; accepted September $16^{\text {th }}, 2012$

\begin{abstract}
The quality of irrigation water from different sources used by urban farmers in the Accra Metropolis was investigated. These were, tap water stored in dugout, surface water (from stream) and wastewater in drains. The samples were analysed for their bacteriological, physical and chemical qualities using standard methods. Analytical Profile Index (API) identification system was used to characterize and identify the bacterial species isolated in the samples. The results showed that heavy metal concentrations in the samples were within the $\mathrm{FAO} / \mathrm{WHO}$ recommended limits for irrigation. The concentrations of highly toxic Lead and Cadmium were even below detection limit. Total and faecal coliform bacteria loads in all three potential irrigation water sources were above the WHO recommended limit for irrigation. Different bacteria species belonging to seven genera were identified in the three irrigation water sources. These included Citrobacter, Chryseomonas, Enterobacter, Klebseila, Proteus, Providencia, Pseudomonas. Generally, the most dominant bacterial species were Pseudomonas aeruginosa and Chryseomonas luteola. Some of these bacteria spp. can pose a health threat to farmers especially those who have challenges with their health and immune system. For example, infection with some of the bacteria species such as Pseudomonas aeruginosa in patients with cystic fibrosis is known to be deadly over periods of time.
\end{abstract}

Keywords: Irrigation Water; Coliform Bacteria; Enterobacteriaceae Heavy Metal

\section{Introduction}

Water is a major input for food production. Its scarcity has often resulted in the use of water of doubtful quality for the production of vegetables in the Accra metropolis. The common sources include potable water from the taps, water from hand-dug wells or streams and even waste water from gutters or open drains. Some of these waters have been reported to be of poor quality and yet used for irrigating vegetables consumed by urban dwellers are polluted [1]. The microbiological contaminants in irrigation water from these sources, in most cases significantly exceed the WHO guideline limit [2]. This is in addition to the presence of heavy metal contamination in the irrigation water which can pose various health risks. Thus, despite the fact that the use of wastewater for irrigation supports livelihoods by generating considerable income for those involved in urban and peri-urban agriculture, it may be, associated with health and environmental risks [3]. Studies have shown that wastewater contains pathogens [4,5], which are transmitted to humans through direct human contact with either the wastewater or con- taminated farm produce. Contamination usually occurs before, during or after irrigation. In addition, the inhalation of aerosols from wastewater can affect farmers and surrounding communities. The rapid rate of urbanization and the consequential rise in surface water pollution by wastewater discharge, combined with the scarcity of freshwater for irrigation in most cities, especially in arid areas, has led to a renewed interest in wastewater irrigation since the 1950 's [6]. It is projected that $18 \%$ of crops are irrigated worldwide with wastewater and this produces $40 \%$ of all food [7]. At least 20 million hectares in 50 countries are irrigated with raw or treated wastewater [8]. [9] estimated that one-tenth or more of the world's population consumes foods that are produced using wastewater. According to [10], urban and peri-urban farmers from different castes and class groups in developing countries in Asia and Africa use wastewater for various activities such as horticulture, fodder production for dairy, agroforestry, orchard keeping, floriculture, aquaculture and cereal production. Increase in yield of crops of about $35 \%$ has been recorded in Nagpur, India, 
when raw wastewater was used as compared to freshwater and chemical fertilizer application [11].

In Ghana, it is reported that most urban centres have no means of treating wastewater and only $4.5 \%$ of households in Ghana are connected to sewer networks [12]. This leaves most untreated wastewater, mainly from domestic sources, ending up in urban drains and water bodies downstream of the cities [13]. It is estimated that about $85 \%$ of this wastewater generated from urban centers end up in the environment in its untreated form, some of which is commonly used in urban irrigated vegetable farming [13]. This water forms a reliable source of irrigation water for these urban vegetable farmers, allowing them to grow perishable vegetables throughout the year.

This study seeks to determine the microbiological, physical and chemical quality of irrigation water used in the Accra Metropolis and to identify which bacteria are present in them. A better understanding of the types and microbial load in the various water sources used for vegetable irrigation in the Accra metropolis will help government and stakeholders to put in place control measures and or satisfactory measures to decentralize water treatment and disinfection systems in the metropolis for the reduction of pathogen contamination levels in wastewater before discharge into the environment.

\section{Methodology}

\subsection{Study Area}

The study was carried out in Accra, the capital city of Ghana which lies within the coastal-savanna zone. Accra has a population of about 3.9 million [14]. It covers an area of about 230 to $240 \mathrm{~km}^{2}$ [13]. The rainfall pattern of Accra is bimodal, with the major season falling between the months of March and June, and a minor rainy season around October. The mean annual rainfall is about 730 $\mathrm{mm}$. The mean temperatures vary from $24^{\circ} \mathrm{C}$ in August to $27^{\circ} \mathrm{C}$ in March and also has a least average monthly humidity of $60 \%$ and the highest not exceeding $75 \%$ [13, 15] The vegetation of Accra consists of dense shrubs without grass in the west and grass with isolated patches of shrub and occasional trees in the east. Baobab and neem trees are also quite common in Accra [15].

\subsection{Sampling Techniques}

\subsubsection{Description of Sampling Sites}

Two main vegetable growing sites were selected in the suburbs of Accra metropolis for the study. These were Dzorwulu and Korle-Bu (Figure 1).

\subsubsection{Dzorwulu Farming Site}

Dzorwulu is one of the major vegetable growing suburbs in the Accra metropolis. The farming site has a total land area of about 12 ha [16]. The sources of water for irrigation are tap water which in most cases are filled and stored in unprotected dugouts using water hose, these dugouts are small ponds about $6 \mathrm{~m}$ in diameter and $1.5 \mathrm{~m}$ deep where farmers store irrigation water before use. The other source is water from the stream (Onyasia stream) which is a tributary of the Odaw River. This stream is polluted with wastewater generated from neighboring settlements.

\subsubsection{Korle-Bu Farming Site}

Korle- $\mathrm{Bu}$ is another major vegetable growing suburb in Accra with a total farming land of about 10 ha [13]. The main source of irrigation water is drain water from houses of hospital staff and surrounding communities, channeled into dugouts.

\subsubsection{Sampling of Water Sources}

Samples of irrigation water from the different sources (stream, tap water and drain), were collected once every month for a period of seven months (September 2007 to March 2008).

Four replicate samples from each of the water sources were taken at a depth of $10 \mathrm{~cm}$ below the water surface into sterilized $200 \mathrm{ml}$ glass bottles and sampling bottles for bacteriological and physico chemical analysis respectively. Each bottle was plunged into the water with its neck facing downwards, and the water transported in insulated box containing ice packs to the laboratory for analysis. Sampling at each site was carried out between 8:00 and 10:00 am in the morning in line with farmers irrigation schedules [17].

\subsection{Determination of Physical and Chemical Parameters}

Determination of $\mathrm{pH}$ and conductivity was done using the Suitex model $\mathrm{pH}$ meter. Available phosphate, nitrate and Sulphate concentrations were determined using standard methods as described in $[18,19]$.

Atomic absorption spectrophotometry (AAS) was used for the determination of heavy metals (Iron, Manganese, Copper, Zinc, Lead and Cadmium) levels in water samples.

\subsection{Microbiological Parameters}

\section{Quantification of Total and Faecal Coliform}

The Multiple Tube Fermentation also referred to as Most Probable Number (MPN) method was used to determine the number of total and faecal coliform bacteria populations in the samples [17]. Aliquot of $1 \mathrm{ml}$ of sample was pipetted into $9 \mathrm{ml}$ of sterile distilled water. The serial dilution prepared for the analysis ranged from $10^{-1}$ to $10^{-9}$. 

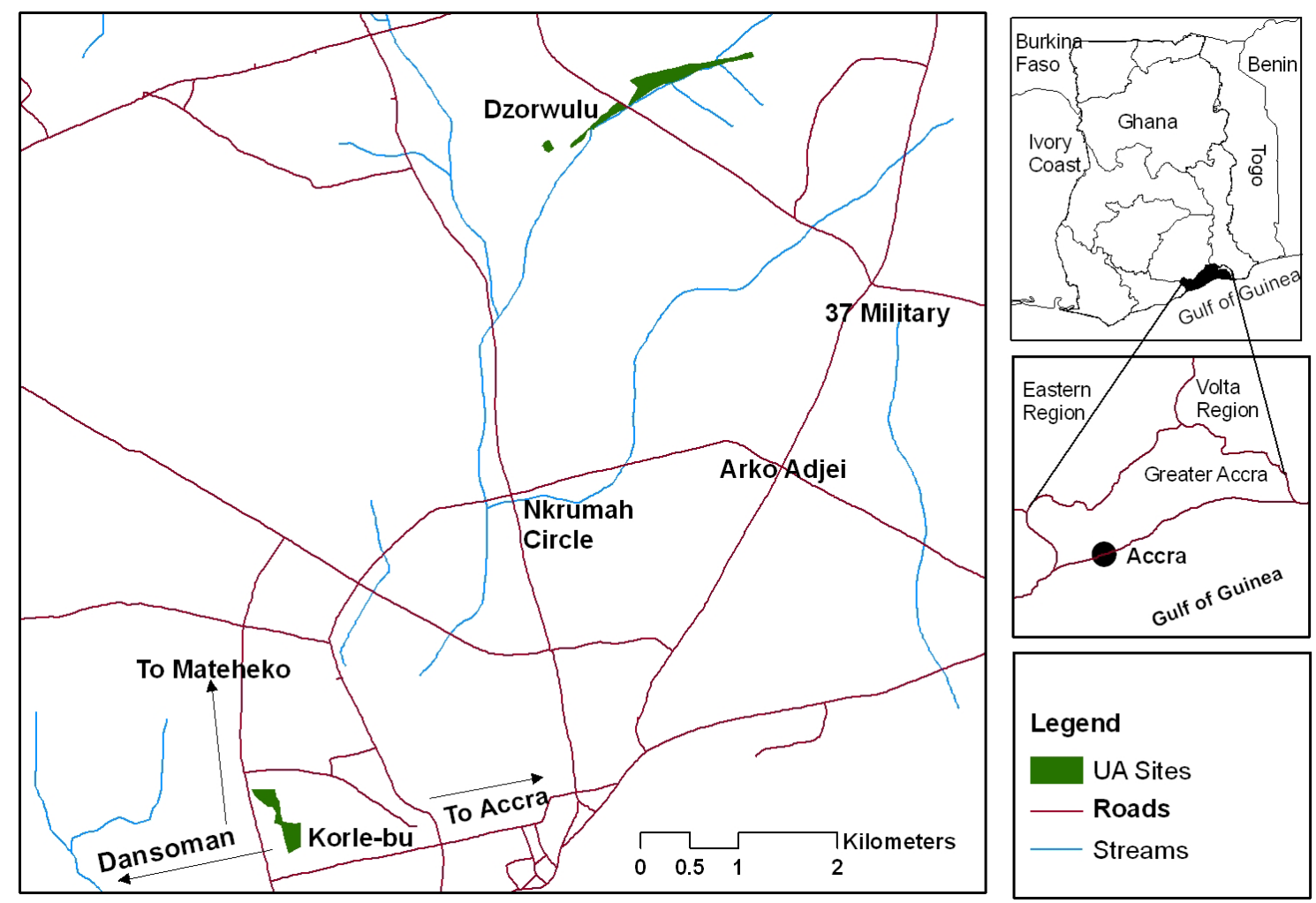

Figure 1. Map of sampling sites.

From each dilution, $1 \mathrm{ml}$ was taken and carefully added in order into triplicate tubes containing $5 \mathrm{ml}$ sterile MacConkey broth with inverted Durham tubes. The tubes were later incubated at $37^{\circ} \mathrm{C}$ for 24 to $48 \mathrm{hrs}$ for determination of total coliform and at $44.5^{\circ} \mathrm{C}$ for the determination of faecal coliform. The number and distribution of positive tubes (acid and/or gas production) from incubated samples were used to obtain the population of coliform bacteria from MPN Table [17].

Aliquot of $1 \mathrm{ml}$ of each sample was inoculated into a tube containing $5 \mathrm{ml}$ of Selenite broth. Selenite broth is enrichment medium for easy identification of Salmonella species in samples. This was then incubated at a temperature of $37^{\circ} \mathrm{C}$ for 24 to $48 \mathrm{hrs}$ for the identification and isolation of Salmonella spp.

\subsection{Isolation of Pure Cultures of Bacteria and Their Identification}

For each sample, one positive MacConkey tube and Selenite broth from all the samples were randomly selected after MPN value had been determined. A loopful of the bacterial culture from the randomly selected positive tubes was then inoculated onto a slant prepared from nutrient agar and was later incubated at $35^{\circ} \mathrm{C}-37^{\circ} \mathrm{C}$ for 24 to $48 \mathrm{hrs}$, for further biochemical tests.

Bacteria from the slant were later suspended into nutrient broth and incubated at $35^{\circ} \mathrm{C}-37^{\circ} \mathrm{C}$ for $18-24 \mathrm{~h}$.
Sterile inoculation loop was then used to transfer a loopful of the bacterial culture onto selective media plates made up of MacConkey agar (BIOTEC) (for other Gram-negative bacteria identification), Salmonella Shigella (SS) agar (BIOTEC) (for Salmonella spp. identification) and Thiosulfate Citrate Bile Salt Sucrose (TCBS) agar (BIOTEC) (for Vibro cholera spp. identification) and incubated at $35^{\circ} \mathrm{C}-37^{\circ} \mathrm{C}$ for the isolation of specific bacteria present [16].

\subsubsection{Determination of Isolates Characteristics}

The technique used for the determination of the isolates followed those outlined in Bergey's manual of systematic bacteriology [20]. In colony morphological characterization, the size, elevations, forms and margins of bacterial colonies and their pigmentation and whether lactose fermentors or non-lactose fermentors on the media were observed. Bacterial colonies differing in their morphological characteristics were randomly selected and purified at least three times. The colonies were purified by picking a bacterial colony which appeared to be composed of one cell type using an inoculating loop. This was then streaked onto the selective agar plates and incubated at $37^{\circ} \mathrm{C}$ for $18-24 \mathrm{hrs}$. After incubation, re-streaking of isolated colony was carried out. This was repeated twice in order to obtain identical colonies. The purity of the bacterial colonies was then confirmed by 
Gram staining. The Gram positive bacteria were dark purple in colour while Gram negative bacteria showed pink colour.

\subsubsection{Biochemical Characterization of Isolated Colonies}

Pure colonies were randomly selected from all the water samples for identification using the Analytical Profile Index (API) 20E system (BioMerieux sa 69280 Marcyl'Etiole/France or bioMerieux, Inc., Hazelwood, MO).

\subsection{Procedures}

\subsubsection{Preparation of the Strip}

An API incubation box (tray and lid) was prepared and 5 $\mathrm{ml}$ of sterile distilled water was distributed into the honeycombed wells of the tray. This was to create a humid atmosphere. The API strip was then placed in it.

\subsubsection{Preparation of Inoculum}

Fresh isolates (18 - 24 hours old) were used for the inoculation. An inoculation pin was used to remove a single well isolated colony from the isolation plate and was carefully emulsified to obtain a homogenous bacterial suspension in a tube containing $5 \mathrm{ml}$ of sterile distilled water.

\subsubsection{Inoculation of the Strip}

API uses miniature microtube reaction chambers. Each microtube consists of a tube and cupule section. Both the tube and the cupule of the test citrate (CIT), Voges Proskauer (VP) and gelatinase (GEL) were filled with the bacterial suspension with the aid of a pipette. The rest of the test was filled only to the tube level (and not the cupule) with the bacterial suspension. Anaerobic conditions were created in the tests arginine dihydrolase (ADH), lysine decarboxylase (LDC), ornithine decarboxylase (ODC), hydrogen sulphide production $\left(\mathrm{H}_{2} \mathrm{~S}\right)$ and urease (URE) by adding mineral oil to the cupule level of the microtube. The incubation box was then closed with the lid and incubated at $35^{\circ} \mathrm{C}-37^{\circ} \mathrm{C}$ for $18-24 \mathrm{hrs}$.

\subsubsection{Reading of Strip}

After 18 - 24 hrs of incubation, the strips were examined by comparing to the reference table, and all spontaneous reactions $(+/-)$ were recorded on the result sheet.

Additional reagents were added to some tests such as: Tryptophane deaminase (TDA) of which a drop of TDA reagent was added to the bacterial suspension in both the tube and the cupule. A dark brown colour indicated a positive reaction which was recorded. One drop of James reagent (BioMerieux sa, 1998) was added to the Indole (IND) test for Indole production. Development of a pink colour in the whole cupule indicated a positive reaction
VP test: a drop each of VP1 and VP2 reagent was added to the tube and was left for 10 mins for reaction to take place. A pink or red colour indicated a positive reaction.

\subsubsection{Interpretation and Identification}

The patterns of the reactions were coded into a numerical profile using the Analytical Profile Index (BioMerieux sa, 1998). On the result sheet, the tests were separated into groups of 3 and a value 1, 2 or 4 as designed by the manufacturer was indicated for each. By adding the values corresponding to positive reactions within each group, a seven digit profile number was obtained for the 20 tests of the API 20 E strip [21].

\subsection{Data Analysis}

SPSS for windows version 15 (SPSS Inc., Chicargo, IL, USA) was used to statistically analyse the data. Faecal and total coliform bacteria populations obtained from MPN were normalized by log transformation before analysis of variance (ANOVA) was performed. Significant differences were analysed by the multiple comparisons procedure of Least Significance Difference (LSD) using a level of significance at $\mathrm{p}<0.05$.

\section{Results}

The Electrical Conductivity (EC) values ranges from $236-265 \mu \mathrm{S} / \mathrm{cm}, 1267-1354 \mu \mathrm{S} / \mathrm{cm}$ and $1296-1893$ $\mu \mathrm{S} / \mathrm{cm}$ in the Tap, Stream and Drain water respectively (Table 1). The multiple comparison (LSD) showed significant difference $(\mathrm{p}<0.05)$ in the mean values of the (EC) between the various water sources. However, the mean values of $\mathrm{pH}$ and (EC) in the irrigation water sources were within the FAO [22] recommended levels for water used for irrigating agricultural crops of 6.5 - 8.4 for $\mathrm{pH}$ and $\leq 3000 \mu \mathrm{S} / \mathrm{cm}$ for EC (Table 1).

\subsection{Nutrients}

The results showed a significant difference in the phosphorus and sulphate concentrations between tapwater and

Table 1. Mean values of physical parameters in the irrigation water.

\begin{tabular}{cccc}
\hline $\begin{array}{c}\text { Water } \\
\text { Source }\end{array}$ & Values & $\begin{array}{c}\mathbf{p H} \\
\mathbf{( p H} \text { units) }\end{array}$ & $\begin{array}{c}\text { Electrical Conductivity } \\
(\boldsymbol{\mu S} / \mathbf{c m})\end{array}$ \\
\hline Tapwater & Range & $6.79-7.28$ & $236-265$ \\
& Mean & 7.00 & 248 \\
Stream & Range & $7.08-7.68$ & $1267-1354$ \\
& Mean & 7.28 & 1307 \\
Drain & Range & $7.14-7.83$ & $1296-1893$ \\
& Mean & 7.46 & 1629 \\
\hline
\end{tabular}


stream water $(\mathrm{p}<0.05)$, and tapwater and drain water sources $(p<0.05)$. Although, the nitrate concentration in the tap water recorded lower value as compared with stream and drain water (Table 2), the concentrations between the three water sources showed no significant difference. The sulphate concentrations ranged from 28.60 to 40.60 and $48,60-79.10 \mathrm{mg} / \mathrm{l}$ in tap and drain water respectively. Even though multiple comparison showed significant difference $(p<0.05)$ between the tapwater and drain as well as tapwater and stream, there was no significant between the stream and drain water. In general, the least nutrient levels were recorded in the tap water while the highest in the drain water (Table 2).

\subsection{Heavy Metals}

The Zinc $(\mathrm{Zn})$ concentrations varied from 0.005 to 0.07 $\mathrm{mg} / \mathrm{l}$ in tapwater and 0.05 to $0.19 \mathrm{mg} / \mathrm{l}$ in stream water. The Iron $(\mathrm{Fe})$ concentration in tapwater and drain water ranged from 0.113 to 2.85 and 0.78 to $2.87 \mathrm{mg} / 1$ respectively. The multiple comparison showed significant difference $(p<0.05)$ in the Manganese $(\mathrm{Mn})$ concentrations between Tapwater source and Stream, Tapwater and Drain and Stream and Drain source. With the exception of tapwater source, the mean Manganese concentrations in the stream and drain water source were slightly above the FAO recommended level of $0.2 \mathrm{mg} / \mathrm{l}$. Generally, the mean heavy metal concentrations in the different irrigation water sources during the study period (Figures 2-5) were lower than the FAO recommended maximum concentration for crop production as cited by [23]. A general trend of tapwater $<$ Stream $<$ Drain was observed in the $\mathrm{Fe}, \mathrm{Mn}$, and $\mathrm{Zn}$ concentrations in the irrigation water. The mean heavy metals concentrations in the different sources of irrigation water (Figures 2-5) were in the trend of $\mathrm{Fe}>\mathrm{Mn}>\mathrm{Zn}>\mathrm{Cu}$. The corresponding values were $1.16,0.44,0.33$ and $0.211 \mathrm{mg} / 1$ respectively.

In the study, concentrations of Lead and Cadmium $(<0.06$ and $<0.025$ respectively) were found to be below detection levels.

\subsection{Coliform Bacteria}

The total and faecal coliform bacterial counts varied considerably amongst the various irrigation water sources examined. Table 3 shows the ranges of these coliform levels.

The results from this study showed varied total and faecal coliform levels in all the three irrigation water sources.

Table 2. Mean concentration of nutrients in irrigation water.

\begin{tabular}{|c|c|c|c|c|}
\hline Source of Irrigation Water & Value & Phosphorus $\left(\mathrm{PO}_{4}\right) / \mathrm{mg} / \mathbf{l}$ & Nitrate $\left(\mathrm{NO}_{3}\right) / \mathrm{mg} / \mathbf{l}$ & Sulphate $\left(\mathrm{SO}_{4}\right) / \mathrm{mg} / \mathrm{l}$ \\
\hline Tapwater & Range & $0.16-0.76$ & $0.18-1.13$ & $28.60-40.60$ \\
\hline \multirow[t]{2}{*}{ Stream } & Range & $1.21-4.63$ & $0.58-4.14$ & $338.30-58.20$ \\
\hline & Mean & $2.8( \pm 1.28)$ & $1.63( \pm 1.48)$ & $49.6( \pm 5.43)$ \\
\hline \multirow[t]{2}{*}{ Drain } & Range & $2.84-3.69$ & $0.15-3.37$ & $48.60-79.10$ \\
\hline & Mean & $3.25( \pm 0.35)$ & $1.78( \pm 1.32)$ & $62.25( \pm 12.97)$ \\
\hline
\end{tabular}

Figures in parentheses are standard deviation.

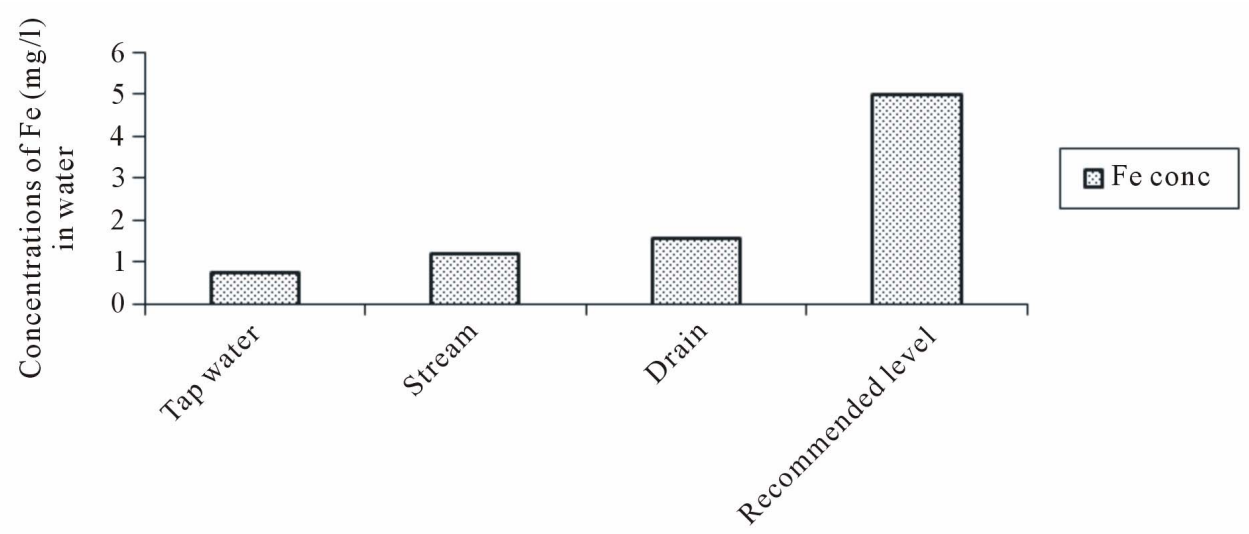

Water Sources

Figure 2. Iron (Fe) concentration in water. 


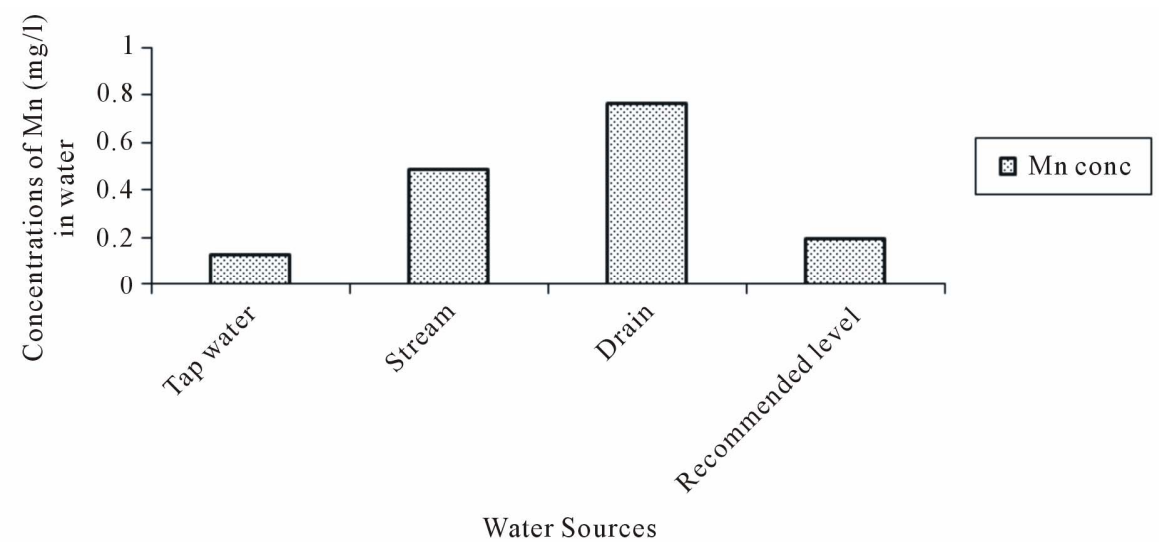

Figure 3. Manganese (Mn) concentration in water.

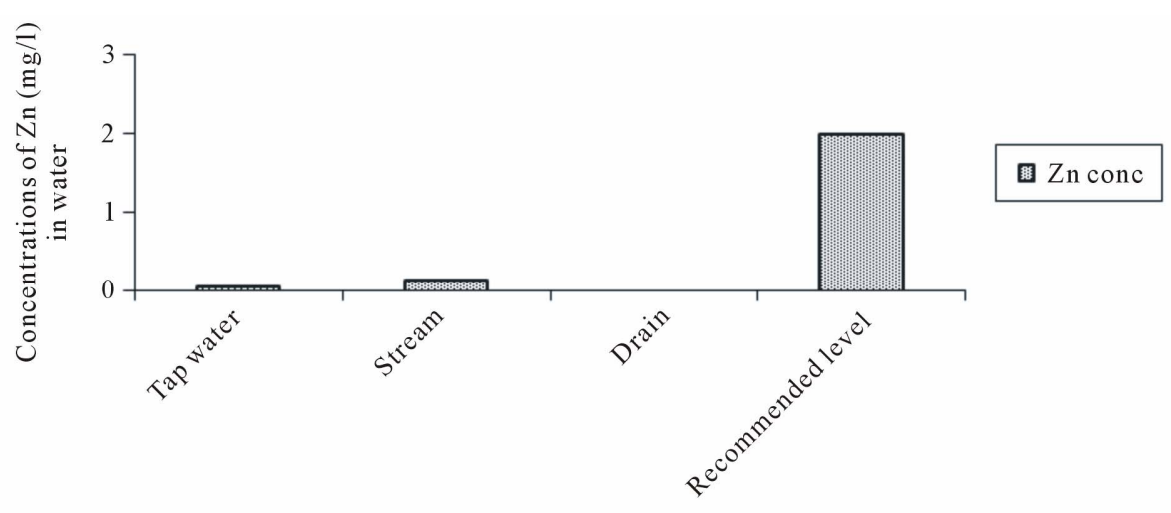

Water Sources

Figure 4. Zinc (Zn) concentration in water.

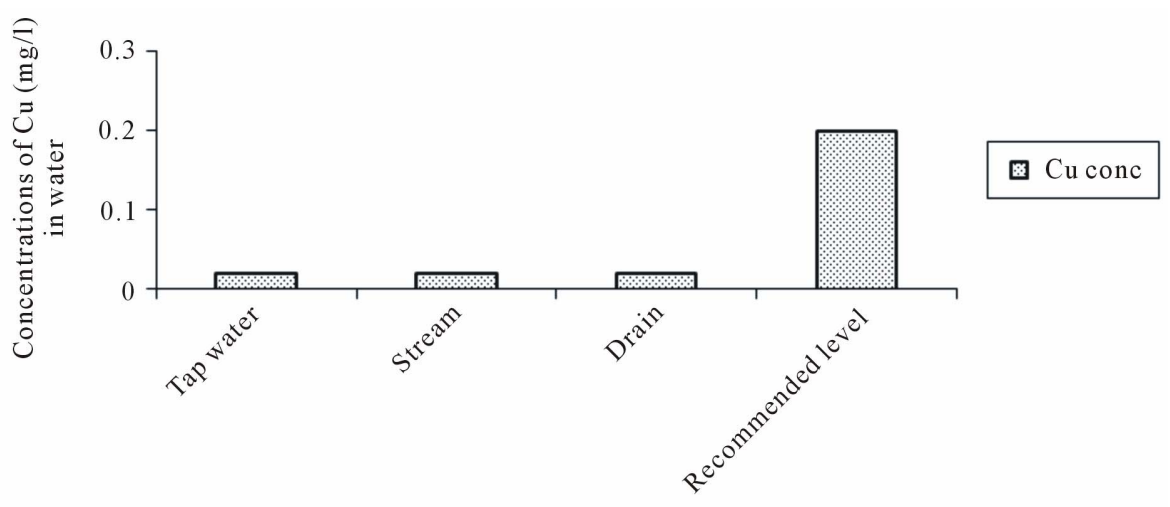

Water Sources

Figure 5. Copper (Cu) concentration in water.

Table 3. Total and faecal coliform level ranges in three irrigation water sources.

\begin{tabular}{cccc}
\hline \multirow{2}{*}{ Sampling site } & Irrigation water sources & \multicolumn{2}{c}{ Ranges of irrigation water (Log MPN/100ml) } \\
\cline { 3 - 4 } & & Total coliform & Faecal coliform \\
\hline Dzorwulu & Tap water & $4.63-7.97$ & $3.37-4.38$ \\
Dzorwulu & Stream & $6.97-9.97$ & $3.97-6.63$ \\
Korle Bu & Drain & $7.97-9.63$ & $5.63-7.38$ \\
\hline
\end{tabular}


On average, the total and faecal coliform counts were lowest in the tap water and highest in the drain irrigation water (Figure 6). Multiple comparison (LSD) showed significant difference $(\mathrm{p}<0.05)$ in both total and faecal coliform levels between tap water and stream, as well as tap water and drain. Both total and faecal coliform bacteria levels of irrigation water sources showed significant differences $(p<0.05)$, with the coliform levels for all irrigation water sources being above the WHO recommended limit of $\leq 1 \times 10^{3} \mathrm{ml}^{-2}$. However there was no significant difference in the means levels of total and faecal coliform $(p>0.05)$ between the stream and drain water sources.

A total of 30 Gram-negative rod bacteria isolates were characterized from the water samples, 10 from each irrigation water source. Thirteen out of the total bacteria isolates resulted in unknown organism. Table 4 shows the distribution of the seventeen bacterial isolates identified in the different water sources. Of all the 17 bacteria species identified, tap water recorded six, stream and drain water five and six, respectively. Chryseomonas luteola was the only one that occurred in all three sources of water. The three species unique to tap water were, Enterobacter cloacae, Pseudomonas putida and Pseudomonas pseudomellei, while only one, Proteus mirabilis, and three, Enterobacter aerogenes, Providencia rettegeri and Chromobacterium violaceum were found in the stream and drain water, respectively.

\section{Discussion}

According to [23], the normal range of $\mathrm{pH}$ for irrigation water is from 6.5 to 8.4 . It therefore suggest that in terms of $\mathrm{pH}$, water from all the three sources were suitable for plant growth and for that matter, for vegetable production. Drain water had the highest $\mathrm{pH}$. A similar drain water $\mathrm{pH}$ ranges were observed in a study by [13]. The relatively higher mean of Electrical conductivity (EC) level $(>700$ $\mu \mathrm{S} / \mathrm{cm})$ in the stream and drain water sources than that of

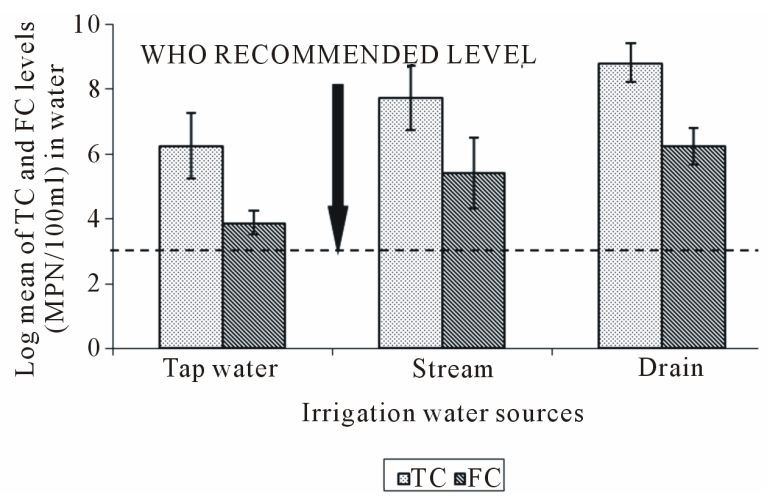

Figure 6. Log geometric mean of total (TC) and faecal coliform (FC) count in irrigation water sources. Bars represent the standard deviation.
Table 4. Enterobacteriaceae and other gram negative bacteria flora present in the irrigation water sources.

\begin{tabular}{lccc}
\hline \multirow{2}{*}{ Isolates } & \multicolumn{3}{c}{ Water source } \\
\cline { 2 - 4 } & Tapwater & Stream & Drain \\
\hline Chryseomonas luteola & + & + & + \\
Enterobacter cloacae & + & - & - \\
Enterobacter sakazakii & + & + & - \\
Pseudomonas aeruginosa & + & + & + \\
Pseudomonas putida & + & - & - \\
Pseudomonas pseudomellei & + & - & - \\
Chromobacterium violaceum & - & - & + \\
Klebsiella pneumoniae & - & + & + \\
Proteus mirabilis & - & + & - \\
Providencia rettegeri & - & - & + \\
Enterobacter aerogenes & - & - & + \\
\hline
\end{tabular}

$(+)$ Indicates the presence of the bacteria species and $(-)$ indicates absence of the bacteria species.

the tapwater could be attributed to high level of dissolved salts in these water sources since effluents from domestic sources (water from household kitchens and bathrooms) are channeled into these water sources. The EC for water used for irrigating agricultural crops is usually expected to be less than $3000 \mu \mathrm{S} / \mathrm{cm}$ [22]. Since for all the three water sources, the ECs were below this value, with the highest being $1893 \mu \mathrm{S} / \mathrm{cm}$ for the drain water, then in terms of salinity, all the three water sources were suitable for irrigation.

The high phosphate, nitrate and sulphate values recorded in the three irrigation water could be attributed to the runoff from the application of fertilizer on the field.

But for the concentration of manganese which was above the FAO recommended maximum concentrations, all the three sources of water would have been satisfactory for irrigation of crops as far as heavy metal contamination is concerned. Even then, according to [24], no health risk has been associated with food containing high manganese concentrations. However, high concentrations of manganese have been reported by [23] to be toxic to some crops. High concentrations of heavy metals, particularly lead and cadmium in food pose serious health problems, including fatal kidney and kidney diseases [25]. The non detectable concentrations of lead and cadmium indicates their low and non-toxic levels in the water sources. This is in agreement with [26] who reported that heavy metals concentrations in general are very low in Ghanaian waters, in our case, due probably to the absence of industries in the study areas. In general therefore, 
the health risks associated with heavy metals in the irrigation water sources appear to be non-existent

The total and faecal coliform counts in all the water sources used were above the WHO [27] recommended standard $\left(1 \times 10^{3} \mathrm{ml}^{-2}\right)$ for unrestricted irrigation of crops, especially those consumed uncooked. The tap water in this case was channeled and stored in dugouts prior to its usage for irrigation. The storage procedure could contribute to contamination of the water in the dugout. However, a studies conducted by [28] at the same site showed that coliform levels found in tap water collected directly from the water hose used by the farmers for irrigation without storage in dugout was zero $0 \mathrm{cfu} / 100 \mathrm{ml}$. The presence of total and faecal coliform counts recorded in the water from the dugout therefore may probably be due to runoff from farmlands containing poultry manure, fertilizers used for the vegetable cultivation and contaminated soils into the dugouts during irrigation. The use of poultry manure and fertilizers are very common at the study site. Besides, the dugouts are not protected and are therefore prone to runoff from surrounding vegetable beds. Bacterial contamination could also be introduced into these dugouts from the feet of farmers who enter barefooted with contaminants such as poultry manure from the field which are stuck under their foot in the act of fetching water for irrigation. [29] reported that faecal coliform levels in poultry manure samples collected from the same site recorded between $1 \times 10^{4}$ to $1 \times 10^{7}$, this is an indication that the presence of poultry manure could contribute to the contamination of the irrigation water. Besides, an earlier studies carried out in Kumasi, showed that fresh poultry manure litter sample used for vegetable production recorded faecal coliform counts between the ranges of $3.6 \times 10^{4}$ and $1.1 \times 10^{7}[30]$.

The high total and faecal coliform levels in stream and drain water sources could be attributed to the discharge of untreated domestic effluents from surrounding houses. The high levels of total and faecal coliform bacteria in our streams has been attributed by [28] to the fact that streams and rivers in most Ghanaian cities are more or less drains and receive untreated wastewater from surrounding communities and from effluents from solid waste dumped near these water bodies. Coliform bacteria contamination levels in different sources of irrigation water obtained from this study agree with the earlier report that low quality water is being used for urban vegetable production in most Ghanaian cities [21,26,31].

The dominant bacterial flora in the irrigation water were Pseudomonas aeruginosa and Chryseomonas luteola (Table 4). Although Chryseomonas luteola which was isolated from all three sources of water belongs to the coliform group, it is more of a normal flora of soil, water and damp environments in tropical to subtropical areas than a human pathogen [32]. It can cause a rare disease called chromobacteriosis in humans. According to [33], most reported cases showed symptoms associated with septicemia, meningitis, endocarditis, or peritonitis.

Pseudomonas aeruginosa which is a nosocomial pathogen is a free living Gram-negative bacterium, commonly found in soils, water and surfaces of plants $[33,34]$, for which reason its presence in the water sources was not surprising. $P$. aeroginosa tolerates to wide variety of physical conditions, including temperature; it is an opportunistic bacterium with high resistance to many commonly used antibiotics and can cause several diseases including urinary tract infections, respiratory system infections, dermatitis, soft tissue infections, bacteremia, bone and joint infections, gastrointestinal infections and a variety of systemic infections, particularly in patients with severe burns and in cancer and AIDS patients who are immunosuppressed [35]. However, this bacterium rarely poses problem for most healthy people.

The presence of Klebsiella pneumoniae was also not surprising, since it has been recorded in the stream and drain water sources. The bacterial spp. is known to cause high fever, chills, flu-like symptoms and pneumonia as well as gastrointestinal symptoms in humans [36].

\section{Conclusion}

Results from the study revealed no evidence of significant pollution of tap water, stream water or drain water with heavy metals that might pose serious threat to human health arising from consuming lettuce irrigated with these potential sources of irrigation water, the situation was different with the microbiological contents. All three types of irrigation water used in the production of vegetables in the Accra metropolis were of great health concern; they contained unacceptably high loads of potentially pathogenic bacteria, levels above those recommended by WHO. Our results are of great importance in vegetable cultivation, since these crops are usually consumed uncooked. Although it appears that most of the bacteria isolated arose more from the neighbouring environment rather than directly from human and animal sources, what is most important is that, they posed greatest danger to persons with health challenges. Farmers in particular, those with health challenges or compromised immune system therefore need to be cautious during irrigation to avoid infection. Furthermore products from the farm should be well washed before consumption.

\section{Acknowledgements}

The authors wish to thank Prof. S. Agyei-Mensah of University of Ghana, Legon, Dr. Philip Amoah and Mr. Ernest Mensah Abraham of International Water Management Institute, and Mr. Maxwell S. K. Akple of Ho 
Polytechnic for their immerse support, technical advice and contribution towards this study. We are also grateful to the vegetable farmers at Dzorwulu and Korle-Bu for their participation.

\section{REFERENCES}

[1] P. Drechsel, S. Graefe, M. Sonou and O. Cofie, "Informal Irrigation in Urban West Africa: An overview," Research Report 102, International Water Management Institute, Colombo, Sri Lanka, 2006.

[2] B. Keraita, P. Dreschsel, and P. Amoah, "Influence of Urban Wastewater on Stream Water Quality and Agriculture in and around Kumasi, Ghana," Environment \& Urbanization, Vol. 15, No. 2, 2003, pp. 171-178. doi: $10.1177 / 095624780301500207$

[3] T. Asano and A. D. Levine, "Wastewater Reclamation, Recycling and Reuse: Past, Present, and Future," Water Science and Technology, Vol. 33, No. 10-11, 1996, pp. 1-16.

[4] R. G. Feachem, D. J. Bradley, H. Garelick and D. D. Mara, "Sanitation and Disease: Health Aspects of Excreta and Wastewater Management," John Wiley \& Sons, Chinchester, 1983.

[5] WHO, "Guidelines for the Safe Use of Wastewater, Excreta and Grey Water: Wastewater Use in Agriculture," Vol. 2, WHO, Geneva, 2006, p. 219.

[6] N. Khouri, J. M. Kalbermatten and C. R. Bartone, "The Reuse of Wastewater in Agriculture: A Guide for Planners," 1994.

[7] P. H. Gleick, "The Worlds Water 2000-2001: The Biennial Report on Freshwater Resources," Island Press, Washington DC, 2000, p. 315.

[8] I. Hussain, L. Raschid, M. Hanjra, F. Marikar and W. van der Hoek, "Framework for Analyzing Socioeconomic, Health and Environmental Impacts of Wastewater Use in Agriculture in Developing Countries," Working Paper 26. International Water Management Institute (IWMI), Colombo, Sri Lanka, 2001, 31 p.

[9] J. Smit and J. Nasr, "Urban Agriculture for Sustainable Cities: Using Waste and Idle Land and Water Bodies as Resources," Environmental and Urbanization, Vol. 4, No. 2, 1992, pp. 141-152.

[10] R. V. Veenhuizen, "Cities Farming for the Future: Urban Agriculture for Green and Productive Cities," 2006, 2 p.

[11] G. B. Shende, "Status of Wastewater Treatment and Agricultural Reuse with Special Reference to India and Research and Development Needs," In: M. B. Pescod and A. Arar, Eds., Treatment and Use of Sewage Effluent for Irrigation, Butterworths, London, 1985, pp. 185-209.

[12] Ghana Statistical Services, "Population and Housing Census; Summary Report of Final Results," Accra, Ghana, 2002, p. 62.

[13] E. Obuobie, B. Keraita, G. Danso, P. Amoah, O. O. Cofie, L. Raschid-Sally and P. Drechsel, "Irrigation Urban Vegetable Production in Ghana: Characteristics, Benefits and Risks," IWMI-RUAF-CPWF, IWMI, Accra, Ghana,
2006, p. 150.

[14] www.ghana.govgh/index.php

[15] K. B. Dickson and G. Benneh, "A New Geography of Ghana," Revised Edition, Longman Group Ltd., Essex, 1995, pp. 17-40.

[16] P. Amoah, "Wastewater Irrigated Vegetable Production: Contamination Pathway for Health Risk Reduction in Accra, Kumasi and Temale-Ghana," Ph.D. Dissertation, Kwame Nkrumah University of Science and Technology, Kumasi, 2008, pp. 74-75.

[17] APHA, AWWA, WEF, "Standard Methods for Examination of Water and Wastewater," 22nd Edition, Washington DC, 2001.

[18] APHA, AWWA, WEF, "Standard Methods for the Examination of Water and Wastewater," 20th Edition, Washington DC, 1995, pp. 3-15.

[19] APHA, AWWA, WEF, "Standard Methods for the Examination of Water and Wastewater," 20th Edition, Washington DC, 1998, pp. 4-146.

[20] J. G. Holt, "Bergey's Manual of Systematic Bacteriology," The Williams and Wilkins Co., Baltimore, 1986.

[21] BioMerieux sa, “API 20 100/20 160. Identification System for Enterobactriaceae and other Gram-Negative Rods," France, 1998, pp. 1-5.

[22] R. S. Ayers and D. W. Westcot, "Water Quality for Agriculture," FAO Irrigation and Drainage Paper 29, FAO, Rome, 1985, 174 p.

[23] M. D. Pescod, "Wastewater Treatment and Use in Agriculture," FAO Irrigation and Drainage Paper 47, Food and Agriculture Organization of the United Nations, Rome, 1992, pp. 125-156.

[24] P. Ghesquiere, "Indirect Wastewater Reuse for Peri-Urban Irrigation in Kumasi, Ghana. Assessment of Surface Water Quality for Irrigation and Its Implications for $\mathrm{Hu}$ man Health," Thesis Submitted in Partial Fulfillment of a Diploma in Water \& Environment, ENGEES, Strasbourg, 1999.

[25] http://www.excelwater.com/eng/b2c/impurities.php

[26] G. A. Cornish, E. Mensah and P. Ghesquire, "Water Quality and Peri-Urban Irrigation: An Assessment of Surface Water Quality for Irrigation and Its Implications for Human Health in the Peri-Urban Zone of Kumasi, Ghana," Report OD/TN 95, September 1999, HR Wallingford Ltd., Wallingford, $44 \mathrm{p}$.

[27] WHO, "Health Guidelines for the Use of Wastewater in Agriculture and Aquaculture," Report of WHO Scientific Group, WHO Technical Report Series No. 778, World Health Organization, Geneva, 1989, p. 74.

[28] R. C. Abaidoo, B. Keraita, P. Amoah, P. Drechsel, J. Bakang, G. Kranjec-Berisavljevic, F. Konradsen, W. Agyekum and A. Klutse, "Safeguading Public Health Concerns, Livelihoods and Productivity in Wastewater Irrigated Urban and Peri urban Vegetable Farming," CPWF PN 38 Project Report, Kumasi, 2011.

[29] P. Amoah, P. Drechsel and R. C. Abaidoo, "Irrigated Urban Vegetable Producyion in Ghana: Sources of Pathogen Contamination and Health Risk Elimination," 
1518 The Quality and Health Implications of Urban Irrigation Water Used for Vegetable Production in the Accra Metropolis

Irrigation and Drainage, Vol. 54, No. S1, 2005, pp. S49S61. doi:10.1002/ird.185

[30] P. Drechsel, R. C. Abaidoo, P. Amoah and O. O. Cofie, "Increasing Use of Poultry Manure in and around Kumasi, Ghana: Is Farmers' Race Consumers' Fate?" Urban Agriculture Magazine, Vol. 2, 2000, pp. 25-27.

[31] P. Mensah, M. Armar-Klemesu, A. S. Hammond, A. Haruna and R. Nyarko, "Bacterial Contamination in Lettuce, Tomatoes, Beef and Goat Meat from the Accra Metropolis," Ghana Medical Journal, Vol. 35, No. 4, 2001, pp. 162-167.

[32] J. Freney, W. Hansen, J. Etienne, F. Vandenesch and J. Fleurette, "Postoperative Infant Septicemia Caused by Pseudomonas Luteola (CDC group Ve-1) and Pseudomonas Oryzihabitans (CDC group Ve-2)," Journal of

\section{List of Abbreviations}

API: Analytical Profile Index;

FAO: Food and Agriculture Organization of the United Nation;

WHO: World Health Organization;

APHA: American Public Health Association;
Clinical Microbiology, Vol. 26, 1988, pp. 1241-1243.

[33] W. Chihab, A. S. Alaoui and M. Amar, "Chryseomonas luteola as the Source of Serious Infections in Moroccan University Hospitals," Journal of Clinical Microbiology, Vol. 42, No. 4, 2004, pp. 1837-1839. doi:10.1128/JCM.42.4.1837-1839.2004

[34] M. R. Silver, T. P. Felegie and M. I. Sorkin, "Unusual Bacterium, Group Ve-2, Causing Peritonitis in a Patient on Continuous Ambulatory Peritoneal Dialysis," Journal of Clinical Microbiology, Vol. 21, 1985, pp. 838-839.

[35] http://www.textbookofbacteriology.net/growth.html

[36] http://www.sproutnet.com/Reports/klebsiella.htm
AWWA: American Water Works Association; WEF: Water Environment Federation;

AAS: Atomic Absorption Spectrophotometry; MPN: Multiple Membrane Filtration; LSD: Least Significance Difference; EC: Electrical Conductivity. 